\title{
Experimental osteoarthritis in rabbits: lesion progression ${ }^{1}$
}

\author{
Wilma N.S. Campos ${ }^{2 *}$, Marcos A. Souza ${ }^{5}$, Thaís Ruiz ${ }^{2}$, Thalita P. Peres ${ }^{3}$, Pedro B. Néspoli ${ }^{5}$, \\ Alessandro T.C. Marques ${ }^{4}$, Edson M. Colodel $^{5}$ and Roberto Lopes de Souza ${ }^{5}$
}

\begin{abstract}
Campos W.N.S., Souza M.A., Ruiz T., Peres T.P., Néspoli P.B., Marques A.T.C., Colodel E.M. \& Souza R.L. 2013. Experimental osteoarthritis in rabbits: lesion progression. Pesquisa Veterinária Brasileira 33(3):279-285. Programa de Pós-Graduação em Ciências Veterinárias, Faculdade de Agronomia, Medicina Veterinária e Zootecnia, Universidade Federal de Mato Grosso, Av. Fernando Corrêa da Costa 2367, Bairro Boa Esperança, Cuiabá,
\end{abstract} MT 78068-900, Brazil. E-mail: wilmavet@gmail.com

The aim of this study was to evaluate the progression of lesions in different stages of osteoarthritis (OA) experimental by radiography (RX), computed tomography (CT), macroscopic and histopathology, linking these different diagnostic methods, helped to provide information that helps the best time for the therapeutic approach. Four experimental periods were delineated at 3, 6, 9 and 12 weeks after induction of $\mathrm{OA}$, known as PI, PII, PIII and PIV, respectively, each with six animals. We evaluated the five compartments of the femorotibial joint: medial femoral condyle (MFC), lateral femoral condyle (LFC), medial tibial plateau (MTP), lateral tibial plateau (LTP) and femoral trochlea (FT). Therefore we established an index by compartment (IC) and by adding such an index was estimated joint femorotibial (IFT). It was observed that the CFM was the compartment with the highest IC also differed significantly $(p<0.05)$ from other compartments. Compartments showed no significant difference ( $p>0.05)$ between the PI and PII, however contrary fact occurred between the PII and PIII $(p<0.05)$, PIII and PIV $(p<0.01)$ and between PI and PIV $(\mathrm{p}<0.001)$. Similarly the IFT, showed a significant difference in the animals of PIV compared to PI $(\mathrm{p}<0.001)$, PII $(\mathrm{p}<0.001)$ and PIII $(\mathrm{p}<0.01)$, and there was no statistical difference ( $p>0.05$ ) between the PI and PII. In the variation of the average interval between periods, there was a higher value between the PIII PIV and for the other intervals of time periods (PI, PII, and PIII-PII). However, these intervals showed no statistically significant difference ( $p>0.05)$. Through the RX, CT, macroscopic and histopathological findings, we found similar patterns among individuals within the same period demonstrating a gradual progression of the disease. These results show that between 3 and 6 weeks progression of the lesion is slower and probably also can be reversed in comparison to other ranges where proved further progression between 9 and 12 weeks after induction of trauma OA. These results may provide a better therapeutic approach aimed at reversing the lesions in early stages of OA. We conclude that the interconnection of the four diagnostic methods individually classified into scores, which were unified in both indices in the evaluation by the femorotibial joint compartment and may represent a diagnostic condition closer to the true condition of the injury and its progression.

INDEX TERMS: Osteoarthritis, progression, diagnosis, injury, rabbits, experimental induction.

\footnotetext{
${ }^{1}$ Received on July 4, 2012.

Accepted for publication on September 4, 2012.

${ }^{2}$ Programa de Pós-Graduação em Ciências Veterinárias, Faculdade de Agronomia, Medicina Veterinária e Zootecnia (Famevz), Universidade Federal de Mato Grosso (UFMT), Av. Fernando Corrêa da Costa 2367, Bairro Boa Esperança, Cuiabá, MT 78068-900, Brazil. *Corresponding author: wilmavet@gmail.com
}

\footnotetext{
${ }^{3}$ Curso de Graduação em Medicina Veterinária, Famevz-UFMT, Cuiabá, MT.

${ }^{4}$ Departamento de Radiologia, Universidade de Cuiabá (Unic), Avenida Beira Rio 3100, Bairro Jardim Europa, Cuiabá, MT 78015-480.

${ }^{5}$ Departamento de Clínica Médica Veterinária (Climev), Faculdade de Agronomia, Medicina Veterinária e Zootecnia (Famevz), Universidade Federal de Mato Grosso, UFMT, Cuiabá, MT.
} 
RESUMO.- [Osteoartrite experimental em coelhos: Progressão lesional.] 0 objetivo deste estudo foi avaliar a progressão das lesões em diferentes períodos da osteoartrite (OA) experimental em coelhos, através da radiografia (RX), tomografia computadorizada (TC), macroscopia e histopatologia, interligar estes diferentes métodos diagnósticos, bem como trazer informações que ajudem na decisão do melhor momento para a abordagem terapêutica. Foram delineados quatro períodos experimentais às $3,6,9$ e 12 semanas após a indução da OA, denominados como PI, PII, PIII e PIV, respectivamente, cada qual com seis animais. Foram avaliados os cinco compartimentos da articulação femorotibial: côndilo femoral medial (CFM), côndilo femoral lateral (CFL), platô tibial medial (PTM), platô tibial lateral (PTL) e tróclea femoral (TF). Por conseguinte, estabeleceu-se um índice por compartimento (IC) e através da soma destes foi obtido um índice da articulação femorotibial (IFT). Observou-se que, o CFM foi o compartimento com maior valor de IC, além disso, diferiu significativamente $(p<0,05)$ dos demais compartimentos. Os compartimentos não apresentaram diferença significativa $(p>0,05)$ entre o PI e o PII, no entanto fato contrário ocorreu entre o PII e o PIII $(p<0,05)$, PIII e PIV $(p<0,01)$ e entre o PI e PIV $(\mathrm{p}<0,001)$. Similarmente o IFT, apresentou diferença significativa nos animais do PIV em relação ao PI $(\mathrm{p}<0,001)$, ao PII $(p<0,001)$ e ao PIII $(p<0,01)$, e não houve diferença estatística $(p>0,05)$ entre o PI e PII. Na variação média dos intervalos entre os períodos, observou-se um maior valor entre o PIII e o PIV em relação aos outros intervalos de períodos (PI-PII e PII-PIII). No entanto, estes intervalos não apresentaram diferença estatisticamente significativa ( $p>0.05)$. Através do RX, TC, macroscopia e histopatológico, verificamos padrões similares entre os indivíduos dentro do mesmo período demonstrando assim uma gradual progressão da doença. Tais resultados evidenciam que entre as 3 e 6 semanas a progressão da lesão é mais lenta e muito provavelmente ainda pode ser reversível em comparação aos outros intervalos onde se comprovou uma maior progressão entre as 9 e 12 semanas após a indução traumática da OA. Estes resultados podem propiciar uma melhor abordagem terapêutica objetivando a reversão das lesões em fases iniciais da OA. Concluímos que, a interligação dos quatro métodos diagnósticos, individualmente classificados em escores e que foram unificados em índices tanto na avaliação por compartimento quanto pela articulação femorotibial pode representar uma condição diagnóstica mais próxima à verdadeira condição da lesão quanto de sua progressão.

TERMOS DE INDEXAÇÃO: Osteoartrite, progressão, diagnóstico, lesão, coelhos, indução experimental.

\section{INTRODUCTION}

Osteoarthritis $(\mathrm{OA})$ is one of the most common joint disease in humans and animals and is related to the deterioration of articular cartilage, subchondral bone and/or synovial membrane, leading to failure of the synovial joint (Amiel et al. 2003, Castro et al. 2006). In the early stages of OA, the lesions may be focused on some of the femorotibial joint compartment, among them the most common is the femo- ral condyles (Kamei, Sumen \& Sakaridani 2008). Injuries resulting from trauma may be reversible if diagnosed early or irreversible due to progressive degeneration of articular cartilage, causing pain, swelling, and loss of limb function (Salminen 2002).

The osteoarthritic changes often are diagnosed in an advanced stage of disease, when the cartilage repair process often has already changed the joint structure. Because of this, new approaches in the treatment of $\mathrm{OA}$, including the development of new drugs, are hampered by the lack of objective and measurable criteria for disease progression (Takahashi et al. 2004). Thus it is essential to know the characteristics of development and progression of cartilage destruction in OA in order to develop and improve diagnostic and therapeutic approaches (Sage \& Turner 2002).

Among the diagnostic methods currently used to assess $\mathrm{OA}$ are non-invasive methods such as radiography (RX), ultrasound, magnetic resonance imaging and computed tomography (CT), and invasive procedures such as arthroscopy, macroscopic and histopathological examination with its advantages and disadvantages (Bruyere et al. 2006). High quality radiographs are accurate in identifying structural changes resulted from $\mathrm{OA}$, but the diagnosis can be challenging in the early stages of the disease (Widmer \& Blevins 1994, Carrig 1997, Mahaffey 1998). The CT scan allows earlier identification of $\mathrm{OA}$ in relation to conventional radiography. The programs of cone beam CT, also in the traditional TC, allow multiplanar reconstructionof the volume scanned, for instance, visualization of axial images, coronal and sagittal sections, as well as 3D reconstruction (Reetz et al. 2006). The macroscopic and histological evaluations are used in many studies as a "gold" standard in the evaluation of disease progression. The scoring system of histological OA introduced by Mankin et al. (1971), is currently the most commonly applied scale. This system was developed to describe the hip OA in humans, but was subsequently applied directly or with modifications to other joints and in various animal models (Pearson et al. 2011).

It is in many situations, more than one diagnostic method, is used to determine the presence and progression (Stickle \& Hathcock 1993, Torelli et al. 2004). The present study aims to evaluate the evolution of lesions associated with different stages of OA by radiography, computed tomography, macroscopic and histopathologic evaluation, linking these different diagnostic methods, as well as provide information that will help to decide the best timepoint to approach therapy considering the increasing trend of secondary lesions in rabbits with experimental OA.

\section{Experimental protocol}

\section{MATERIALS AND METHODS}

We used 24 male New Zealand white, rabbits, aged 5-6 months and weighing 2.0 to $3.0 \mathrm{~kg}$, from the Central Animal House of Federal University of Mato Grosso, Brazil. For the animals inclusion criteria for the study bilateral joints femorotibia radiographs were used in craniocaudal and mediolateral projections, for the verification of the absence of structural changes in the joints.

For the experimental induction of $\mathrm{OA}$, we used the technique of cranial cruciate ligament transection (CCLT), proposed by Yoshioka et al. (1996) with modifications. The animals were 
anesthetized intramuscularly with ketamine (S Agener Ketamine $^{\circledR} 10 \%, 50 \mathrm{mg} / \mathrm{kg}$ ), midazolam $(2 \mathrm{mg} / \mathrm{kg}$ ) and meperidine (Dolosal ${ }^{\circledR}, 10 \mathrm{mg} / \mathrm{kg}$ ) and maintained with isoflurane mask (Isoforine $^{\circledR}$ ). After trichotomy and antisepsis of the surgical area, parapatellar incision was made medial in the right knee, followed by arthrotomy and lateral dislocation of the patella, the cranial cruciate ligament (CCL) was then sectioned without injuring the adjacent structures. The joint was irrigated with sterile saline and synthesis of joint capsule was made using polyglactin 910 (Vicryl $^{\circledR} 5-0$ ) in simple continuous pattern, subsequent synthesis of the skin using nylon (Shalon ${ }^{\circledR}$, sutures) 3-0 in simple interrupted pattern. For analgesia and prevention of infection after surgery, animals were treated subcutaneously with cephalothin sodium $(12.5 \mathrm{mg} / \mathrm{kg})$ every 6 hours for 7 days and morphine (Dimorf ${ }^{\circledR} 3 \mathrm{mg} / \mathrm{kg}$ ) every four hours for 4 days. The animals were housed in appropriate room and housed in individual cages measuring $70 \mathrm{~cm} \times 70 \mathrm{~cm} \times 70 \mathrm{~cm}$, fed with standard comercial pellets and water ad libitum.

Subsequently, the animals were devided into four experimental periods referred to as PI, PII, PIII and PIV, each of six animals, which were respectively evaluated at 3, 6, 9 and 12 weeks after induction of OA by X-ray, CT, macroscopically and histopathologically. These four diagnostic procedures were performed in five different compartments of the femorotibial joint: medial femoral condyle (MFC), lateral femoral condyle (LFC), medial tibial plateau(MTP), lateral tibial plateau (LTP) and femoral trochlea (FT). Since each diagnostic method was evaluated by two independent observers in a blind study, they were unaware of the samples evaluated in relation to their periods.

\section{Image}

Radiographs were obtained in craniocaudal and mediolateral projections of thefemorotibial joint using X-ray machine set with $300 \mathrm{~mA} / 56 \mathrm{kV}$, screens and films of medium speed and revelation by an automatic processor Vision ${ }^{\circledR}$ line, LX-2 model. To obtain the CT images, we used an apparatus for cone beam computed tomography (i-Cat ${ }^{\circledR}$, Imaging Sciences International, Hatfield, Pennsylvania, USA), in which the animals were positioned supined with the knee extended right, and the detection limits were determined by na initial cursor proximal to the femorotibial joint and a cursor on the end of the tibial tuberosity. The acquisition time was 20 seconds, using 0.2 at full resolution voxel, 64 kilovolt $(\mathrm{kV})$ and 3.2 milliamps per second (mAs). After its acquisition, the images were downloaded to a computer alocated in adjoining room, where the animals could observed through plumbiferous glass. In a subsequent step was carried out detailed evaluation of axial images, coronal, sagittal, and oblique slices with a thickness of $76 \mu \mathrm{m}$ using a 3D software (Kodak ${ }^{\circledR}$ imaging). Both examinations were performed with the animals under general anesthesia.

For both methods of diagnostic imaging the evaluation parameters were: presence and size of osteophytes (grade $0=$ absent, $1=$ small degree, grade $2=$ moderate, grade $3=$ severe) and subchondral sclerosis (grade $0=$ absent, grade $1=$ mild, $2=$ moderate degree, grade 3 = severe) according to Torelli et al. (2004) with modifications. Through the sum of these two parameters, a partial score was assigned to each compartment evaluated and total joint score was obtained by the sum of the parts of each compartment, the joint being scored from 0 to 30 , both the RX and CT. At the end of the respective periods and imaging studies, animals were euthanized by intramuscular injection of $50 \mathrm{mg} / \mathrm{kg}$ ketamine sodium $10 \%$ and after 10 minutes, anesthetized with intravenous overdose of sodium thiopental (Thiopentax ${ }^{\circledR}$ ). This study was approved by the Ethics Committee on Animal Research at the Federal University of Mato Grosso (CEPA-UFMT), registered under the Protocol No. 23108.035345/10-5.

\section{Macroscopic evaluation}

Immediately after animals euthanasia the femorotibiais joints were dissected, examined macroscopically and the compartments were classified according to criteria established by Laverty et al. (2010), with modifications. To grade 0 (absent) surface was normal, smooth and without significant alterations, to grade 1 (mild), rough, with minimal fibrillation on the articular surface; to grade 2 (moderate), rough surface, with erosion and/or the presence of osteophytes, but without exposure of subchondral bone; to grade 3 (severe), there is erosion with exposure of subchondral bone injury and repair in the presence of marginal osteophytes and intense bone remodeling. A total joint score was obtained by summing the partial scores of each compartment scored from 0 to 15. The lesions were then documented using a digital câmera (Nikon D7000, Tokyo, Japan).

\section{Histopathologic evaluation}

Samples were taken from each compartment joint, fixed in $10 \%$ buffered formalin solution for 48 hours, decalcified in a solution of $5 \%$ formic acid for 1 week. These were then processed in gradients of alcohol and xylene, embedded in paraffin blocks and stained with hematoxylin and eosin (H \&E). The histological slides were evaluated by scale according to the criteria established by Mankin et al. (1971). Thus, the partial score of each compartment was obtained by calculating the evaluation system standardized by the Osteoarthritis Research Society International (OARSI) and established by Bao et al. 2009 and Rutgers et al. 2010 where sco$\mathrm{re}=$ grade $\mathrm{x}$ stage, grade (scale, $0-6$ ) was defined as OA depth progression into cartilage irrespective of its horizontal extent; stage (scale, 0-4) was defined as the horizontal extent of cartilage involvement within one side of a joint compartment irrespective of the underlying grade; score (scale, 0-24) was defined as assessment of combined OA grade and OA stage. Thus the partial score ranged from 0 to 24 in each compartment, and the total joint score was obtained by summing the partial scores.

\section{Statistical analysis}

The data were tabulated in spreadsheets, and established a rate per compartment (IC) using partial scores according to each diagnostic procedure ( $\mathrm{Rx}=\mathrm{x}$-ray, computerized tomography $\mathrm{Tc}=$, Macro= macroscopic and histopathology =Histo) the following formula:

$$
0>\frac{\mathrm{Rx}}{6}+\frac{\mathrm{Tc}}{6}+\frac{\text { Macro }}{3}+\frac{\text { Histo }}{24}<1 \text {; }
$$

Thus, the IC varied 0-1 and femorotibial índex (IFT) varied from 0 to 5, obtained by adding the ICs of the five compartments evaluated. Data were analyzed regarding their normal distribution using the Kolmogorov-Smirnov test. Therefore, the normal data were compared using one-way ANOVA, subjected to analysis of variance ( $F$ test) and in cases of significant $F$ test, means were compared using the Tukey test. The values were analyzed using the computer program R (2012). For all statistical analyzes was adopteda significance level of $5 \%$.

\section{RESULTS}

In the case of ICs, it was observed that the focal lesions were more severe in the MFC, followed by MTP in all periods. Since the FT was the compartment that had the lowest value of IC (Fig.1). There was a statistically significant difference $(\mathrm{p}<0.05)$ between MFC and MTP and between these and the other compartments (LFC, LTP and FT), in each period (Table 1). All compartments evaluated showed 


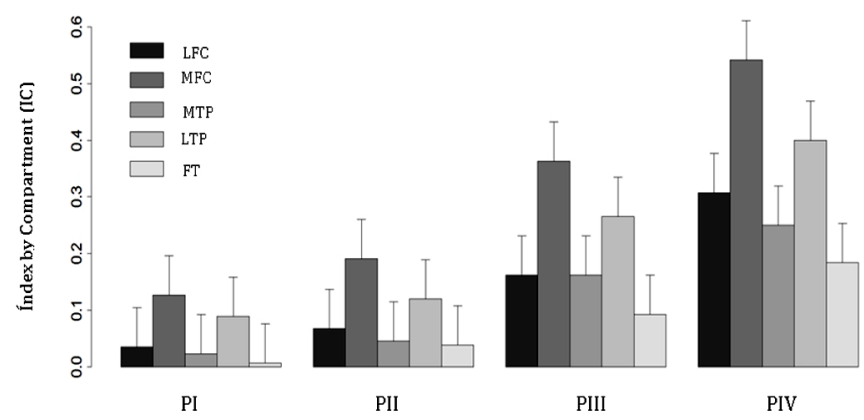

Fig.1. Schematic representation of the mean variations of the ICs in each compartment articular (CFM: medial femoral condyle; CFL: lateral femoral condyle; PTM: medial tibial plateau: PTL: lateral tibial plateau and TF: femoral trochlea) to 3 (PI), 6 (PII), 9 (PIII) and 12 (PIV) weeks after induction of OA in rabbits. Notes the highest and lowest value of IC to CFM and TF, respectively, in all periods. Values expressed as mean and standard deviation.

no statistically significant difference $(p>0.05)$ between the PI and PII, however different fact occurred between the PII and PIII $(\mathrm{p}<0.05)$, PIII and PIV $(\mathrm{p}<0.01)$ and between the PI and PIV $(\mathrm{p}<0.001)$, as shown in Table 1.

Similarly the IFT, showed a significant difference in the animals of PIV compared to PI $(\mathrm{p}<0.001)$, PII $(\mathrm{p}<0.001)$ and PIII ( $\mathrm{p}<0.01)$, and there was no statistical difference between the PI and PII, as shown in Figure 2. Analyzing the va-

Table 1. Average values of the partial indices of joint compartments, obtained by radiography, CT, macroscopic and histopathologic at different stages of $\mathrm{OA}^{*}$

\begin{tabular}{ccccc}
\hline Compartments $^{\mathrm{b}}$ & PI & PII & PIII & PIV \\
\hline MFC & $0,13 \pm 0.05^{\mathrm{Ac}}$ & $0,19 \pm 0,09^{\mathrm{Ac}}$ & $0,36 \pm 0,13^{\mathrm{Ab}}$ & $0,54 \pm 0,10^{\mathrm{Aa}}$ \\
LFC & $0,03 \pm 0,03^{\mathrm{Cc}}$ & $0,07 \pm 0,06^{\mathrm{Cc}}$ & $0,16 \pm 0,10^{\mathrm{Cb}}$ & $0,31 \pm 0,10^{\mathrm{Ca}}$ \\
MTP & $0,09 \pm 0,07^{\mathrm{Bc}}$ & $0,12 \pm 0,11^{\mathrm{Bc}}$ & $0,27 \pm 0,07^{\mathrm{Bb}}$ & $0,40 \pm 0,12^{\mathrm{Ba}}$ \\
LTP & $0,02 \pm 0,03^{\mathrm{Cc}}$ & $0,05 \pm 0,04^{\mathrm{Cc}}$ & $0,16 \pm 0,07^{\mathrm{Cb}}$ & $0,25 \pm 0,12^{\mathrm{Ca}}$ \\
FT & $0,01 \pm 0,01^{\mathrm{Cc}}$ & $0,04 \pm 0,04^{\mathrm{Cc}}$ & $0,09 \pm 0,05^{\mathrm{Cb}}$ & $0,18 \pm 0,08^{\mathrm{Ca}}$
\end{tabular}

aAssessments conducted at 3, 6, 9 and 12 weeks after induction of OA (PI, PII, and PIII PIV, respectively) through the cranial cruciate ligament transection of the rabbits. bMFC: medial femoral condyle; LFC: lateral femoral condyle; MTP: medial tibial plateau; LTP: lateral tibial plateau and FT: femoral trochlea. Means followed by same uppercase and lowercase in the column on the line do not differ by Tukey test at $5 \%$ nominal significance.

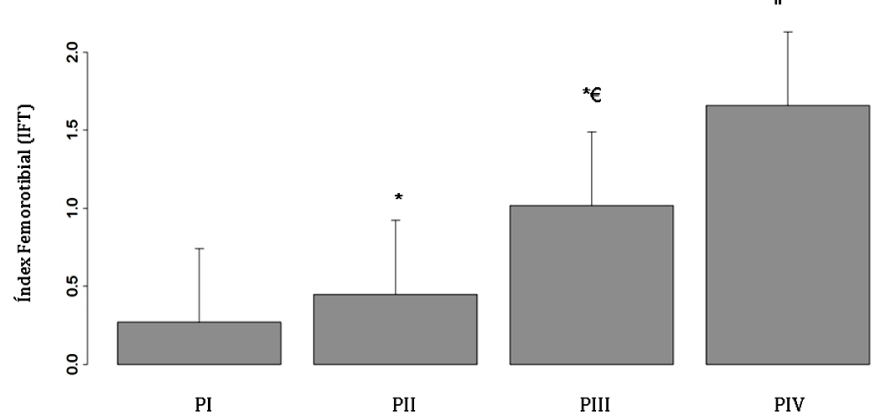

Fig.2. Schematic representation of the mean values of the IFT (femorotibial Index) obtained by X-ray, CT scan, macroscopic and histopathological findings at different stages of experimental OA in rabbits. PI, PII, and PIII PIV 3, 6, 9 and 12 weeks respectively. Values are expressed as mean and standard deviation. ${ }^{*} \mathrm{P}<0.05$ vs. IP; $€{ }^{*} \mathrm{p}<0.05$ vs PII, ${ }^{*} \mathrm{p}<0.01$ vs PIII

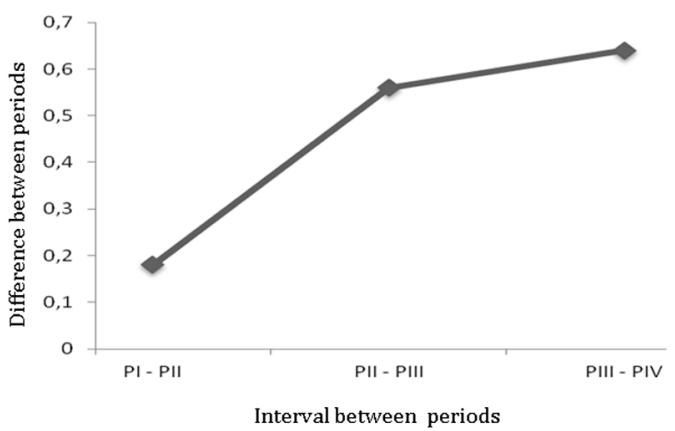

Fig.3. Schematic representation of the means values between periods of 3 (PI), 6 (PII), 9 (PIII) and 12 (PIV) weeks after induction of experimental $\mathrm{OA}$ in rabbits. Notes the highest interval between PIII and PIV. However, no statistically difference ( $p>0.05)$ was noted.

riation of the average interval between periods, there was a greater interval value between the PIII PIV and for the other intervals of time periods (PI, PII, and PIII-PII). Nevertheless, these intervals showed no statistically significant difference ( $p>0.05)$ as shown in Figure 3. By radiography, $\mathrm{CT}$, macroscopic and histopathological findings, we found similar patterns among individuals within the same period demonstrating a gradual evolution of the disease. In $\mathrm{PI}$, mild signs of osteolysis was the only obvious change to imaging tests (X-rays and CT) and, in most animals, no signs of $\mathrm{OA}$ were features observed in the radiographic examination. Macroscopically, the articular surface proved to be a rough exterior and small fibrillations, only the MFC and the MTP. While the major histopathological changes were hypertrophy, cracks and disorientation of the columns of chondrocytes, as illustrated in Figure 4a.

In PII, the main radiographic changes included mild subchondral sclerosis but the animal five of the period showed moderate level for this parameter. By CT was observed signs of osteolysis and osteophyte formation. The macroscopic changes were observed as surface roughness, atrial, formation of small gaps and erosion (Fig.4b). Disruption of the cartilage surface, hypertrophic chondrocytes, disorientation and clusters proliferation of chondrocytes in the column less than $10 \%$ evaluated in the entire region, were found in histological changes over time.

In PIII, radiographic and tomographic included, presence of osteophytes, sclerosis and osteolysis, most evident in MFC (Figure 4c). By gross analysis was evident signs of fibrillation, erosion, and fibrocartilage. On histologic evaluation showed the formation of cysts in the middle zone, hyperplasia and cellular disorganization. In PIV, it was evident the formation of multiple osteophytes, sclerosis and bone remodeling by the intense X-rays and CT scans. Moreover, the joints showed thickness articular capsule erosion total thickness of bone cartilage, deterioration of the meniscus, soft tissue fibrosis and osteophytes the presence of X-ray (Fig.4d). The macroscopic, there was erosion of the articular surface, wear and presence of osteophytes. For the histopathology of the lesions changes were found extending for more than $50 \%$ of the region evaluated, such as cyst formation, fibroplasia and repair. 

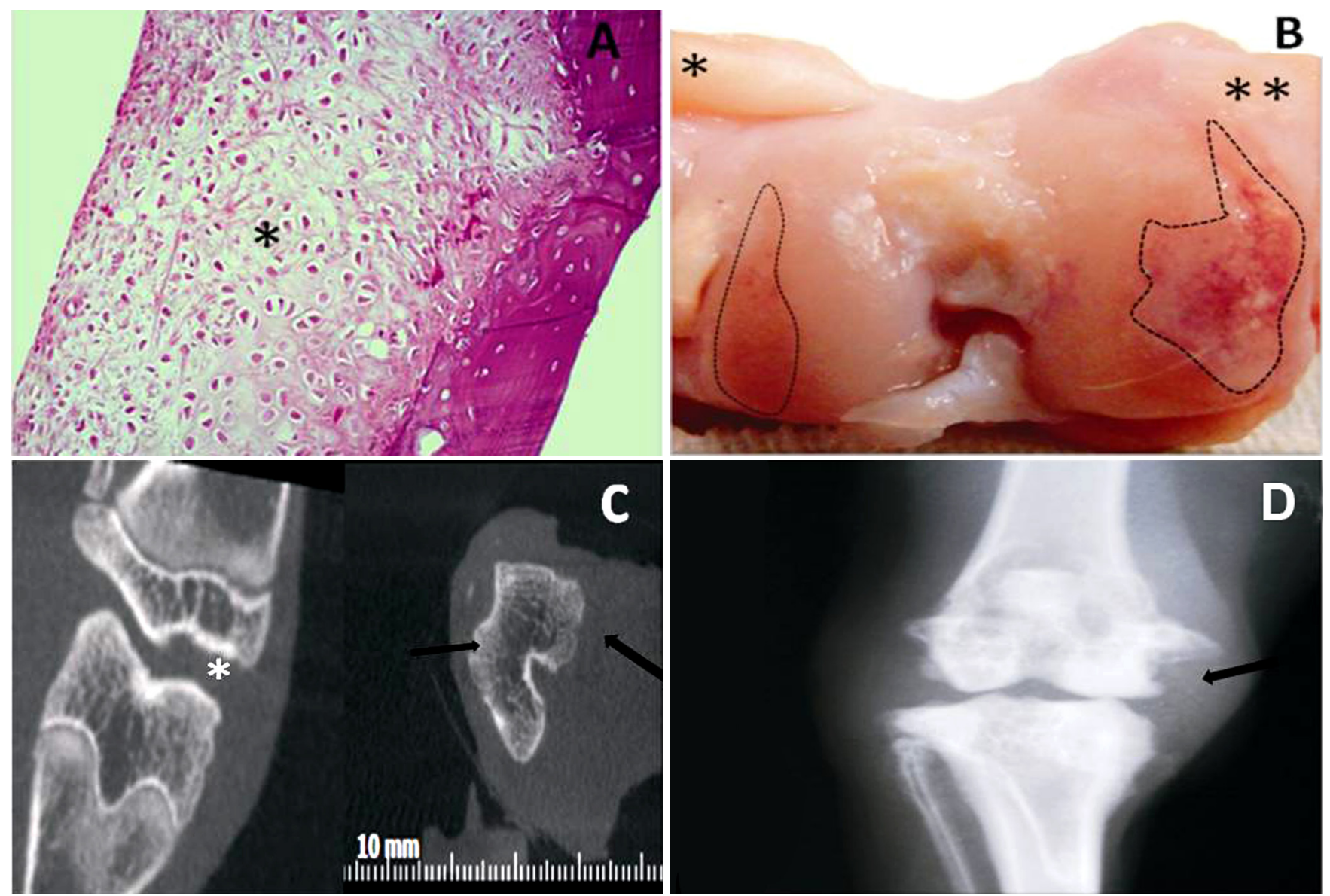

Fig.4. (A) Histological appearance, (B) macroscopic, (C) CT, and (D) X-ray, at 3, 6, 9 and 12 weeks respectively after the induction of experimental rabbits in OA. (A) Observe intense disorientation of the columns of chondrocytes and extracellular matrix deposition distributed unevenly in the articular cartilage $\left({ }^{*}\right)$ in the CFM. HE, 20x; (B) rough aspect and erosion, $\left({ }^{*}\right)$ CFL - initial lesion (dashed outline), (**) CFM - advanced lesions (dashed outline); (C) Note areas of sclerosis $(*)$ in the medial portion tibiofemoral joint and the axial projection of the medial femoral condyle (MFC) observed in B, note bone osteolysis and bone remodeling in CFM (arrow); (D) regions presenting femorotibial joint sclerosis, osteophytes (arrows) and intense bone remodeling in the medial compartments (CFM and PTM).

\section{DISCUSSION AND CONCLUSIONS}

The initial loss of articular cartilage in early OA is classically considered a focal process that can progressively involve all joint compartments, inducing biological changes in the molecular composition of the joint surfaces (Lorenz \& Richter 2006). Tiraloche et al. (2005), evaluating the effect of glucosamine on cartilage degradation in rabbits, observed differences in therapeutic responses between the regions analyzed, and no effect on MFC and MTP, indicating greater severity in these compartments. Such fact could also be demonstrated in our study, which evaluated the five compartments, the MFC and MTP were the most affected.

Similarly, Buchanan \& Kean (2002) and Glasson (2007) report that in humans the medial compartment is the most commonly involved, which should, however, relate this to the presence and functionality of the meniscus, and the medial meniscus is the most injured, precisely because it is more attached and monitor the movements of the tibia at the knee. However, according Sah et al. (1997), this effect depends on the chronicity of traumatic injury. The same authors also reported that in acute lesions induced by CCLT, the lateral meniscus and the LFC are the most adversely affected due to the large rotational forces created.

In chronic lesions, the medial compartments are the most affected as result of repeated episodes of cranial translation of the tibia. Nevertheless, this study showed higher medial compartments gravity in all periods. These discrepancies can be attributed to the species studied and the mode of exercise trauma. Furthermore, the extent of injury of cartilage appears to be highly dependent on the joint region, which can be explained by different loading conditions in different regions (Lorenz \& Richter 2006). This explains the fact that the FT compartment be less commonly affected in all periods in this study is characterized as an area of lower joint friction, and yet the lower levels of stress.

Another important fact observed in this study is that the highest and lowest values increase from the interval between periods occurred between the PIII and PIV and PI and PII, respectively. It can be observed based on the studies discussed above, there was an increase in the intensity of the lesions, which is probably due to an environment created by CCLT instability in a period longer than six weeks. For this same fact has been observed in humans by 
O'Connor, Laughlin \& Woods (2005) and Richardson et al. (2007) in a similar study.

We believe that this fact gives also the chronic and irreversible lesions of articular cartilage in the later periods of OA, because according to Salminen (2002) with the progression of lesions, tissues degenerate more rapidly than can be regenerated. Mainly due to the erosions of cartilage matrix and death of the chondrocytes articular cartilage $\mathrm{OA}$ advanced. This erosion is associated with extracellular matrix degradation by proteolytic enzymes, exceeding the amount and speed of production of new matrix. This phenomenon has a strong influence of inflammatory cytokines released from fibroblasts and macrophages, which can perpetuate and lead to an irreversible process of degeneration of cartilage (Sandell \& Aigner 2001).

In this study, the different diagnostic methods were able to show the progression of OA lesions during the study periods. The model used CCLT to induce morphological changes allowed the evaluation of this common disease, as described by Biasi et al. (2005), Gonçalves et al. (2008) and Melo et al. (2008). The development and progression of OA occurred due to joint instability, which changed the distribution of weight on the joint (Glasson et al. 2007, Herzog \& Longino 2007). In PI and PII, the histological findings in this study as the presence of few areas of atrial and rare cluster groups, as observed in the superficial and middle layers, are found also found in normal cartilage under mechanical induction, not being associated OA (Fernandes et al. 1998). However, Hashimoto et al. (1998) report that in the initial phase of $\mathrm{OA}$ degeneration is often observed in articular surface in the form of disruption of the columns of chondrocytes, as disclosed in our study.

However, it should be noted that the rate of disease progression appears to be highly dependent on the species studied. While Graverand Le et al. (2002) found a level of 9.10 using the criteria established by Mankin et al. (1971) as early as 3 weeks after CCLR in rabbits, these levels were observed in dogs after 12 weeks of induction of OA (Lorenz 2005).

Although in our study the values of the interval between periods have not shown statistically significant difference between them, show that between 3 and 6 weeks the lesion progression is slower and most likely can still be reversed in comparison to other intervals which proved further progression between 9 and 12 weeks after induction of trauma $\mathrm{OA}$. The extrapolation of experimental results to the clinical routine is not always possible and should be done with caution, because events such as the chronic instability and pre-existing degenerative changes present in clinical cases, can not be disregarded. Moreover, these results are important because they can provide a better therapeutic approach aimed at reversing the damage still in early stages of OA.

We conclude that the interconnection of the four diagnostic methods (radiography, tomography, macroscopic and histopathology), individually classified into scores, which were unified in both indices in the evaluation by the femorotibial joint compartment and may represent a diagnostic condition closer to the true condition of the lesion and its progression.
Acknowledgements.- To Coordenação de Aperfeiçoamento de Pessoal de Nível Superior (CAPES) for providing graduate student stipend; to the trainees Keyla D'Agostin, Dábila Sonego for helping during the experiment; and to. Prof. Dr. Anderson Castro for their assistance in the statistical analyzes.

\section{REFERENCES}

Amiel D., Toyoguchi T., Kobayashi K., Bowden K., Amiel M.E. \& Healey R.M. 2003. Long term effect of sodium hyaluronate (Hyalgan) on osteoarthritis progression in a rabbit model. Osteoarth. Cartil. 9:636-643.

Bao J.P., Chen W.P., Feng J., Zhao J., Shi Z.L. \& Huang K. 2009. Variation pattern of two degradation enzymes systems in articular cartilage in different stages of osteoarthritis: regulation by dehydroepiandrosterone. Clin. Chim. Acta 408:1-7.

Biasi F., Rahal S.C. \& Volpi R.S. 2005. Reconstrução do ligamento cruzado cranial em cães, associado ou não ao sulfato de condroitina. Arq. Bras. Med. Vet. Zootec. 57:442-447.

Bruyere O., Collette J., Kothari M., Zaim S., White D. \& Genant H. 2006. Osteoarthritis, magnetic resonance imaging, and biochemical markers: a one year prospective study. Ann. Rheum. Dis. 65:1050-1054.

Buchanan W.W. \& Kean W.F. 2002. Osteoarthritis. III. Radiological and clinical definition. Inflammopharm. 10:53-78.

Carrig C.B. 1997. Diagnostic imaging of osteoarthritis. Veter. Clin. North Am., Small Anim. Pract. 27:777-813.

Castro R.R., Cunha F.Q., Silva F.S. \& Rocha F.A.C. 2006. A quantitative approach to measure joint pain in experimental Osteoarthritis - evidence of a role for nitric oxide. Osteoarth. Cartil. 14:769-776.

Fernandes J.C., Martel-Pelletier J., Lascau-Coman V., Moldovan F., Jovanovic D. \& Raynauld J.P. 1998. Collagenase-1 and collagenase- 3 synthesis in normal and early experimental osteoarthritic canine cartilage: an immunohistochemical study. J. Rheumatol. 25:1585-1594.

Glasson S.S., Blanchet T.J. \& Morris E.A. 2007. The surgical destabilization of the medial meniscus (DMM) model of osteoarthritis in the 129/SvEv mouse. Osteoarth. Cartil. 15:1061-1069.

Gonçalves G., Melo E.G. \& Gomes M.G. 2008. Effects of chondroitin sulfate and sodium hyaluronate on chondrocytes and extracellular matrix of articular cartilage in dogs with joint disease. Arq. Bras. Med. Vet. Zootec. 60:93-102.

Hashimoto S., Ochs R.L., Komiya S. \& Lotz M. 1998. Linkage of chondrocyte apoptosis and cartilage degradation in human osteoarthritis. Arthritis Rheum. 41:1632-1638.

Herzog W. \& Longino D. 2007. The role of muscles in joint degeneration and osteoarthritis. J. Biomech. 40:54-63.

Kamei G., Sumen Y. \& Sakaridani K. 2008. Evaluation of cartilage defect at medial femoral condyle in early osteoarthritis of the knee. Magn. Reson. Imag. 26:567-571.

Laverty S., Girard C.A., Williams J.M., Hunziker E.B. \& Pritzker P.H. 2010. The OARSI histopathology initiative e recommendations for histological assessments of osteoarthritis in the rabbit. Osteoarth. Cartil. 18:53-65.

Le Graverand M.P., Eggerer J., Vignon E., Otterness I.G., Barclay L. \& Hart D.A. 2002. Assessment of specific mRNA levels in cartilage regions in a lapine model of osteoarthritis. J. Orthop. Res. 20:535-544.

Lorenz H., Wenz W., Ivancic M., Steck E. \& Richter W. 2005. Early and stable upregulation of collagen type II, collagen type I and YKL40 expression levels in cartilage during early experimental osteoarthritis occurs independent of joint location and histological grading. Arthritis Res. Ther. 7:156-165.

Lorenz H. \& Richter W. 2006. Cellular and molecular changes in degenerating cartilage. Progr. Histochem. Cytochem. 40:135-163.

Mahaffey M.B. 1998. The stifle and tarsus, p.194-199. In: Thrall D.E. (Ed.), Textbook of Veterinary Diagnostic Radiology. $3^{\text {rd }}$ ed. Saunders Elsevier, Philadelphia.

Mankin H.J., Dorfman H., Lippiell L. \& Zarins A. 1971. Biochemical and metabolic abnormalities in articular cartilage from osteoarthritic human hips: Correlation of morphology with biochemical and metabolic data. J. Bone Joint Surg. Am. 53:523-537. 
Melo E.G., Nunes V.A. \& Rezende C.M.F. 2008. Sulfato de condroitina e hialuronato de sódio no tratamento da doença articular degenerativa em cães. Estudo histológico da cartilagem articular e membrana sinovial. Arq. Bras. Med. Vet. Zootec. 60:83-92.

O'Connor D.P., Laughlin M.S. \& Woods G.W. 2005. Factors related to additional knee injuries after anterior cruciate ligament injury. Arthroscopy 21:431-8.

Pearson R.G., Kurien T., Shu K.S.S. \& Scamell B.E. 2011. Histopathology grading systems for characterisation of human knee osteoarthritis e reproducibility, variability, reliability, correlation, and validity. Osteoarth. Cartil. 19:324-331.

Pritzker K.P.H., Gay S., Jimenez S.A., Ostergaard K. \& Pelletier J.P. 2006. Osteoarthritis cartilage histopathology: grading and staging. Osteoarth. Cartil. 14:13-29.

R Development Core Team 2012. R: A language and environment for statistical computing. R Foundation for Statistical Computing, Vienna, Austria. ISBN 3-900051-07-0, URL <http://www.R-project.org/>

Reetz J.A., Mai W., Muravnick K.B., Goldschmidt M.H. \& Schartz T. 2006. Computed tomographic evaluation of anatomic and pathologic variations in the feline nasal septum and paranasal sinuses. Vet. Radiol. Ultrasound 47:321-327.

Rocha I.D., Moraes T.M.S., Rezende M.U. \& Pécora J.R. 2007. Avaliação da evolução de lesões associadas à lesão do ligamento cruzado anterior. Acta Ortop. Bras. 15:105-108.

Rutgers M.. Van Pelt M.J.P., Dhert W.J.A., Creemers L.B. \& Saris D.B.F. 2010. Evaluation of histological scoring systems for tissue-engineered, repaired and osteoarthritic cartilage. Osteoarth. Cartil. 18:12-23.

Sage A.M. \& Turner T.A. 2002. Ultrasonography of the soft tissue structures of the equine foot. Equine Vet. Educ. 14:212-221.
Sah R.L., Yang A.S., Chen A.C., Hant J.J., Halili R.B. \& Yoshioka M. 1997. Physical properties of rabbit articular cartilage after transection of the anterior cruciate ligament. J. Orthop. Res. 15:197-203.

Salminen H.J., Saamanen A.M., Vankemmelbeke M.N., Auho P.K., Perala M.P. \& Vuorio E.I. 2002. Differential expression patterns of matrix metalloproteinases and their inhibitors during development of osteoarthritis in a transgenic mouse model. Ann. Rheum. Dis. 61:591-597.

Sandell L.J. \& Aigner T. 2001. Articular cartilage and changes in arthritis: An introduction on cell biology of osteoarthritis. Arthritis Res. 3:107113.

Stickle R.L. \& Hathcock J.T. 1993. Interpretation of computed tomographic images. Vet. Clin. North Am. 23:417-435.

Takahashi M., Naito K., Abe M., Sawada T. \& Nagano A. 2004. Relationship between radiographic grading of osteoarthritis and the biochemical markers for arthritis in knee osteoarthritis. Arthritis Res. Ther. 16:208-212.

Tiraloche G., Girard C., Chouinard L., Sampalis J., Moquin L., Ionescu M., Reiner A., Poole R. \& Laverty S. 2005. Effect of oral glucosamine on cartilage degradation in a rabbit model of osteoarthritis. Arthritis Res. 52:1118-1128.

Torelli S.R., Rahal S.C., Volpi R.S., Yamashita S., Mamprim M.J. \& Crocci A.J. 2004. Radiography, computed tomography and magnetic resonance imaging at 0.5 Tesla of mechanically induced osteoarthritis in rabbit knees. Braz. J. Med. Biol. Res. 37:493-501.

Yoshioka M., Coutts R.D., Amiel D. \& Hacker S.A. 1996. Characterization of a model of osteoarthritis in the rabbit knee. Osteoarth. Cartil. 4:87-98.

Widmer W.R., Buckwalter K.A., Braunstein E.M., Hill M.A., O'Connor B.L. \& Visco D.M. 1994. Radiographic and magnetic resonance imaging of the stifle joint in experimental osteoarthritis of dogs. Vet. Radiol. Ultrasound 35:371-383. 